\title{
Studies on the Role of Arginine Vasotocin in Relation to Oviposition in Laying Hens
}

\author{
Tadashi NAKADA ${ }^{1)}$, Tomoki SoH ${ }^{2)}$, Tetsurou Shiota ${ }^{2)}$ \\ and Kousaku TANAKA ${ }^{2)}$ \\ ${ }^{1)}$ Department of Animal Science, University of the Ryukyus, \\ Nishihara-cho, Okinawa-ken 903-1 \\ ${ }^{2)}$ Department of Animal Science, Kyushu University, \\ Higashi-ku, Fukuoka-shi 812
}

\begin{abstract}
The role of arginine vasotocin (AVT) was investigated in relation to oviposition in laying hens. The posterior pituitary of fowl hens was removed $1-2 \mathrm{~h}$ before oviposition of the mid-clutch egg, but all hens so treated laid at the expected time of oviposition. The administration of AVT antiserum ( $1 \mathrm{ml} /$ fowl hen or $0.3 \mathrm{ml} /$ quail hen) had no effect on oviposition time. It is suggested that AVT released from the posterior pituitary may not act directly to cause the expulsion of the uterine egg.
\end{abstract}

Key words : arginine vasotocin, oviposition, fowl hen, quail hen

(Jpn. Poult. Sci., $31: 358-362,1994$ )

\section{Introduction}

It is well known that there is a high degree of regularity in the time interval between which the successive eggs in a clutch are laid by the hen (ATOwOOD, 1929; HEYWANG, 1938). Since a close relation between the time of oviposition and a succeeding ovulation in a given clutch has been reported by WARREN and SCOTT (1935) and PHILLIPS and W ARREN (1937), the time of ovulation can be predicted within rather narrow range from the individual hen's record of laying. RIDDLE (1921) and Burrows and BYERLY (1942) demonstrated that the administration of posterior pituitary preparations to the hen caused a premature expulsion of a uterine egg. Vasotocin were found in the posterior pituitary of the hen (Munsick et al., 1960) and from in vitro and in vivo studies, arginine vasotocin (AVT) was found to be the most potent oxy tocic substance (MUNSICK et al., 1960 ; Heller and Pickering, 1961). The phenomenon of ovipostion, i.e. the expulsion of the egg from the oviduct, is accompanied by a marked increase in the concentration of blood AVT (TANAKA and NAKAJO, 1962 ; STURKIE and LiN, 1966 ; TANAKA et al., 1984). It has been considered that AVT plays an important role in the induction of oviposition in birds. In earlier works (TANAKA and NAKADA, 1974 ; TANAKA and GoTO, 1976 ; TANAKA, 1976), however, the ovarian oviposition-inducing factor (OOIF) has been found in pre- or post-ovulatory follicles. This OOIF is assumed to be the action of prostaglandins (PGs) (DAY and NALBANDOv, 1977), since they have a potent activity to induce premature oviposition in quail (HERTELENDy, 1972) and fowl (HERTELENDY et al. 
1975), and were found to be markedly increased in the largest follicle shortly before oviposition and in peripheral blood plasma (OLson et al., 1986). On the other hand, it is postulated that PGF enhances the release of vasotocin that acts as an additive action to the effects of PGF and further stimulates uterine contractility through binding with the uterine membrane receptor (SHIMADA and SAITO, 1989). No satisfactory conclusion about the mechanisms of oviposition has been established.

The present study was conducted to clarify whether AVT released from posterior pituitary is a direct trigger of oviposition in domestic birds.

\section{Materials and Methods}

\section{Animals}

Birds from White Leghorn strain, aged 7-14 months and Japanese quail (Coturnix coturnix japonica), aged 1-3 months were used. They were maintained in individual laying cages fitted with automatic oviposition recorders and were exposed to a $14-\mathrm{h}$ photoperiod. All birds selected for study were producing clutches of more than 4 eggs with a pause of only a single day between clutches.

\section{Hypophysectomy}

The posterior lobe of White leghorn hen was removed according to the method of OpEL (1965). Immediately after the removal that was completed $1-2 \mathrm{~h}$ before the expected time of oviposition, hens were returned to their individual cages and oviposition time was recorded. For removal of both the anterior and posterior pituitaries, the posterior lobe was removed first, followed by removal of the anterior lobe through the same surgical hole by sucking. For sham operation, the sphenoid bone was drilled, stopping just before reaching the sella membrane and the dental drill was pulled out, followed by closing the incision. This served as a control. All hens were killed $2-4 \mathrm{~h}$ after oviposition and the completeness of the lobectomy was verified in all birds.

\section{Preparation of antiserum to AVT}

AVT antiserum (R2-Kyushu) produced on our laboratory (Goto et al., 1986) was used. This antiserum showed 91\% binding to AVT at a final dilution of $1: 100$ and about $40 \%$ binding at a final dilution of $1: 100,000$, which did not show significant cross -reaction with oxytocin or mesotocin but showed $51 \%$ cross-reactivity with vasopressin, when the serum from White leghorn hen was tested. A single dose of 1 $\mathrm{ml}$ antiserum/fowl hen or $0.3 \mathrm{~m} l$ /quail hen was injected intravenously $8 \mathrm{~h}$ before the expected time of oviposition of the mid-clutch egg (Cs). After injection, birds were returned to their individual cages and oviposition time was checked. When oviposition time was more than $2 \mathrm{~h}$ late, it was considered a delay.

\section{Results}

As shown in Table 1, all of the 6 hens that were subjected to removal of the posterior pituitary 1-2 $\mathrm{h}$ before the expected time of oviposition laid at the normal time. Similarly, 4 hens with lack of both anterior and posterior pituitaries were laid at normal oviposition time. After autopsy, posterior pituitaries of 2 hens that were subjected to posterior lobectomy only were found to be incompletely removed. They 
laid at the expected time. Sham operated hens also laid at the normal time. Thus, all of the operated hens including control laid normally.

Administration of $1 \mathrm{~m} l$ of AVT antiserum into fowl hens $8 \mathrm{~h}$ before the estimated time of oviposition had no effect on the time of the lay in any of the 5 hens so treated. The same results were obtained in all of the 9 quail hens, when $0.3 \mathrm{~m} l$ of AVT antiserum was given in the same manner as to the fowl hens. No delayed oviposition was observed in this experiment.

\section{Discussion}

OPEL (1966) removed the posterior pituitary on the day before expected lay of the terminal $(\mathrm{Ct})$ egg of a sequence with 2 eggs, and he observed that the oviposition time was unaffected by the removal. However, it was considered that his experiment was not a reasonable design, because if the largest follicle destined to ovulate next is removed (TANAKA and NAKADA, 1974) or blockaded from its ovulation by a hormone (Nys, 1987), the uterine Cs egg at the time of treatment is known to behave as a Ct egg in oviposition time. Therefore, the present experiment was conducted to remove the posterior pituitary 1-2 $\mathrm{h}$ before the expected oviposition of Cs egg. However, the Cs egg was laid at the expected time in all cases. The report that removal of the posterior pituitary does not affect normal laying (SHIRLEY and Nalvandov, 1956) supports our results. In this concern, OpEL (1966) has shown that oviposition in neural lobectomized

Table 1. Effect of hypophysectomy on the time of oviposition of $\mathrm{C}_{2}$ egg in the domestic fowl

\begin{tabular}{lccc}
\hline \multicolumn{1}{c}{ Operation* } & No. of hens operated & $\begin{array}{c}\text { No. of hens laid at } \\
\text { expected time }\end{array}$ & $\begin{array}{c}\text { No. of hens laid at } \\
\text { delayed time }\end{array}$ \\
\hline $\begin{array}{l}\text { Removal of posterior } \\
\text { pituitary }\end{array}$ & 6 & 6 & 0 \\
$\begin{array}{c}\text { Removal of both } \\
\text { anterior and posterior } \\
\text { pituitaries }\end{array}$ & 4 & 4 & 0 \\
$\begin{array}{l}\text { Incomplete removal of } \\
\text { posterior pituitary }\end{array}$ & 2 & 2 & 0 \\
$\begin{array}{c}\text { Control } \\
\text { (Sham operation) }\end{array}$ & 6 & 6 & 0 \\
\hline
\end{tabular}

* All hypophysectomies were completed 1-2 $\mathrm{h}$ before expected time of oviposition.

Table 2. Effect of injection of AVT antiserum into fowl and quail hens on oviposition time

\begin{tabular}{ccccc}
\hline Birds & $\begin{array}{c}\text { Amount of AVT } \\
\text { antiserum* }\end{array}$ & $\begin{array}{c}\text { No. of hens } \\
\text { injected }\end{array}$ & $\begin{array}{c}\text { No. of hens laid at } \\
\text { expected time }\end{array}$ & $\begin{array}{c}\text { No. of hens laid at } \\
\text { delayed time }\end{array}$ \\
\hline Fowl & $1 \mathrm{~m} l$ & 5 & 5 & 0 \\
Quail & $0.3 \mathrm{~m} l$ & 9 & 9 & 0
\end{tabular}

* A single dose of AVT antiserum was injected intravenously $8 \mathrm{~h}$ before the expected oviposition time of mid-clutch egg. 
hens might account for an abrupt release of AVT from the stalk-median eminence region. In order to rule out such a problem, AVT antiserum was administered into hens. However, oviposition time was unaffected, though the amount of the antiserum given was considered to be enough to neutralize the blood AVT. Scince the R2Kyushu antiserum has a binding activity of $91 \%$ at a final dilution of $1: 100$, the amount of the antiserum given, $1 \mathrm{ml} /$ fowl hen or $0.3 \mathrm{ml}$ /quail hen, was considerd to be enough to neutralize the blood AVT in both cases. However, determination of hen's blood AVT to see whether it is actually neutralized with AVT antiserum still remains to be tested.

In view of the present results, it is suggested that AVT released from the posterior pituitary may not act directly to cause the expulsion of the uterine egg. As mentioned by ShImAda and SAIto (1989), the AVT released at oviposition may have an additive action to the effects of PGF. However, further study will be needed to fully understand the mechanism of oviposition, since the origin of PGF at the laying of the Ct egg is not clearly understood.

\section{References}

ATowood, H. (1929) Observations of concerning the time factor in egg production. Poultry Science, $8: 137-140$.

Burrows, W.H. and T.C. Byerly (1942) Premature expulsion of eggs by hens following injection of whole posterior pituitary preparations. Poultry Science, $21: 416-421$.

DaY, S.L. and A.V. Nalbandov (1977) Presence of prostaglandin F (PGF) in hen follicles and its physiological role in ovulation and oviposition, Biology of Reproduction, $16: 486-494$.

Goto, K., K. TANAKA and T. Terao (1986) Production of antiserum for radioimmunoassay of arginine vasotocin. Japanese Journal of Zoothechnical Science, $57: 614-619$.

HELLER, H. and B.T. PICKERING (1961) Neurohypophysial hormones of non-mammalian vertebrates. Journal of Physiology, London, 155 : 98-114.

Hertelendy, F. (1972) Prostaglandin-induced premature oviposition in the coturnix quail. Prostaglandins, $2: 269-279$.

HeRTELENDY, F., H.V. BiEller and H. Todd (1975) Effects of the egg cycle and route of administration on prostaglandin-induced oviposition of hens and Japanese quail. Journal of Reproduction and Fertility, $44: 579-582$.

Heywang, B.W. (1938) The time factor in egg production. Poultry Science, $17: 240-247$.

Munsick, R.A.,W.H. SAwyer and H.B. VAN Dyke (1960) Avian neurohypophysial hormones: Pharmacological properties and tentative identification, Endocrinology, 66 : 860-871.

Nys, Y. (1987) Progesterone and testosterone elicit increase in the duration of shell formation in domestic hens. British Poultry Science, 28 : 57-68.

Olson, D.M., K. ShImAdA and R.J. ETChes (1986) Prostaglandin concentrations in peripheral plasma, and ovarian and uterine plasma and tissue in relation to oviposition in hens. Biology of Reproduction 35 : 1140-1146.

OpEL, H. (1965) Release of oviposition-inducing factor from the median eminence-pituitary stalk region in neural lobectomized hens. Anatomical Record $154: 396$.

PHILLIPS, R.E. and D.C. WARREN (1937) Observations concerning the mechanics of ovulation in the fowl. Journal of Experimental Zoology, $76: 117-136$.

RidDLE, O. (1921) A simple method of obtaining premature eggs from birds. Science, 54 : 664-666.

Shimada, K. and N. Saito (1989) Control of oviposition in poultry. Critical Reviews in Poultry Biology, CRC press, inc. Vol. 2, Issue 3, pp 235-253.

Shirley, H.V. JR. and A.V. Nalvandov (1956) Effects of neurohypophysectomy in domestic chickens. Endocrinology, $58: 477-483$.

StURKIE, P.D. and Y.C. LiN (1966) Release of vasotocin and oviposition in the hen. Journal of 
Endocrinology, $35: 325-326$.

TANAKA, K. (1976) Oviposition-inducing activity in the ovarian follicles of different sizes in the laying hen. Poultry Science, 55 : 714-716.

Tanaka, K. and K. Goto (1976) Partial purification of the ovarian oviposition-inducing factor and estimation of its chemical nature. Poultry Science, 55 : 1774-1778.

TANAKA, K., K. Goto, T. YoshiokA, T. Terao and O. KogA, (1984) Changes in the plasma concentration of immunoreactive arginine vasotocin during oviposition in the domestic fowl. British Poultry Science, 25 : 589-595.

TANAKA, K., and T. NAKADA, (1974) Participation of the ovarian follicle in control of time of oviposition in the domestic fowl. Poultry Science, $53: 2120-2125$.

TANAKA, K. and S. NAKAJO (1962) Participation of neurohypophysial hormone in oviposition in the hen. Endocrinology, $70: 453-458$.

W Arren, D.C. and H.M. Scott (1935) The time factor in egg formation. Poultry Scince 14 : $195-207$.

\title{
鶏及びゥズラの放卵に対するアルギニン・バゾトシンの 関連性について
}

\author{
仲田 正 ${ }^{1)} \cdot$ 宗 知紀 ${ }^{2)} \cdot$ 塩田 鉄朗 ${ }^{2)} \cdot$ 田中耕作 ${ }^{2)}$ \\ ${ }^{1)}$ 琉球大学農学部, 沖縄県西原町千原 903-01 \\ 2) 九州大学農学部, 福岡市東区 812
}

\begin{abstract}
連産中の鶏及びゥズラを用いてアルギニン・バゾトシ ン（AVT）の放卵に関連する役割を検討した。推定放卵 時刻の 1 ～時間前に雌鶏の下垂体後葉を除去した。し かしすべての個体が推定放卵時刻に放卵した。また，推 定放卵時刻の 8 時間前にAVT 抗血清 $1 \mathrm{~m} l$ を鶏に, 0.3
\end{abstract} $\mathrm{m} l$ をウズラにそれぞれ㙁脈投与したが，放卵時刻に影
響は無かった。これらの結果から, 下垂体後葉から放出 される AVT は放卵を自接誘起する作用はないものと推 察された。

（家禽会誌, $31: 358-362,1994)$ キーワード：アルギニン・バゾトシン，放卵，鶏， ウズ ラ 